\title{
Genetic correlations between pulpwood and solid-wood selection and objective traits in Eucalyptus globulus
}

\author{
Matthew G. Hamilton ${ }^{1 *}$, Brad M. Potts ${ }^{1}$, Bruce L. Greaves $^{1}$, Greg W. DutKowski ${ }^{2}$ \\ ${ }^{1}$ School of Plant Science and Cooperative Research Centre for Forestry, University of Tasmania, Private Bag 55, Hobart TAS 7001, Australia \\ ${ }^{2}$ PlantPlan Genetics Pty Ltd, Private Bag 55, Hobart TAS 7001, Australia
}

(Received 1 May 2009; accepted 17 October 2009)

\author{
Keywords: \\ volume / \\ survival / \\ basic density / \\ Janka hardness / \\ checking
}

\begin{abstract}
- If selective breeding is to be successful, significant genetic variation must be present in the traits targeted for improvement (i.e. "objective traits").

- This study aimed to quantify genetic variation in Eucalyptus globulus pulpwood and sawn-timber objective traits (rotation-age whole-tree volume, survival, whole-tree basic density, sawn-board Janka hardness and sawn-board internal checking) and estimate additive genetic correlations between these and inexpensively-assessed "selection traits".

- Significant genetic variation was identified in all objective traits at the subrace and/or family within subrace level.

- Selection-age diameter at breast height $(1.3 \mathrm{~m}, \mathrm{DBH})$ was strongly genetically correlated with rotation-age volume (0.78) and survival (0.82). Subrace and additive genetic correlations of selectionage Pilodyn penetration with rotation-age $12-\times-12-\mathrm{mm}$-sample basic density $(-0.70$ and -0.75 respectively) and whole-tree basic density ( -0.83 and -0.91 respectively) were also strong.

- No significant subrace or additive genetic correlation between wood-sample gross shrinkage and sawn-board internal checking was detected. However, subrace and additive genetic correlations of sawn-board Janka hardness with Pilodyn penetration ( -0.75 and -0.58 respectively) and sample gross shrinkage ( -0.77 and -0.73 respectively) were significantly different from zero.

- These findings suggest that genetic improvement of the examined objective traits is possible through selective breeding, although none of the assessed selection traits were strongly correlated with internal checking.
\end{abstract}

Résumé - Corrélations génétiques entre traits objectifs de sélection pour le bois de pâte et le bois massif d'Eucalyptus globulus.

- Pour qu'un programme d'amélioration soit couronné de succès, une variabilité génétique significative doit être présente dans les traits cibles de la sélection.

- Cette étude visait à quantifier les variations génétiques des traits cibles du bois à pâte et du bois de sciage d'Eucalyptus globulus (âge de révolution, volume de l'arbre entier, survie, infradensité de l'arbre entier, indice de dureté de Janka des sciages et fissures internes des sciages) et à estimer les corrélations génétiques additives entre ces traits et une sélection de caractéristiques évaluées à peu de frais.

- Des variations génétiques significatives ont été détectées pour tous les traits cibles au niveau de la provenance et/ou de la famille dans la provenance.

- Le diamètre à hauteur de poitrine $(1,3 \mathrm{~m}, \mathrm{DBH})$ présentait une forte corrélation génétique avec le volume en fin de révolution $(0,78)$ et la survie $(0,82)$. Les effets de provenance et les corrélations génétiques additives ont été forts entre le coefficient de pénétration de Pilodyn et l'infradensité d'un échantillon de $12-\times-12-\mathrm{mm}$ ( $-0,70$ et $-0,75$ respectivement $)$ et l'infradensité des arbres entiers $(-0,83$ et $-0,91$ respectivement).

- Aucun effet provenance et aucune corrélation génétique additive n'ont été détectés entre le coefficient de retrait du bois de l'échantillon brut et les fissures internes des sciages. Toutefois, des effets provenance et des corrélations génétiques additives dont été détectés entre l'indice de dureté Janka des sciages et l'indice de pénétration Pilodyn $(-0,75$ et $-0,58$ respectivement) ou le coefficient de retrait de l'échantillon brut ( $-0,77$ et $-0,73$ respectivement).

\footnotetext{
* Corresponding author: matthew.hamilton@utas.edu.au
} 
- Ces résultats suggèrent que l'amélioration génétique des traits-cibles examinés est possible par le biais d'une sélection bien qu'aucun des traits cibles évalués n'était fortement corrélé avec un contrôle interne.

\section{INTRODUCTION}

There are large areas of E. globulus plantation in Australia (c. 454000 ha in 2005; Parsons et al., 2006), Chile (c. 232000 ha in 2003), Portugal (c. 700000 ha in 2002) and Spain (c. 500000 ha in 2002) (Potts et al., 2004). Although pulpwood production is the principal focus of most E. globulus growers, there is increasing interest in producing sawn timber, particularly high-value appearance-grade products, from plantations (Greaves et al., 2004; Nolan et al., 2005; Raymond, 2000). Breeding, along with improved silviculture and the adoption of appropriate processing practices, is one means of improving the profitability of plantations grown for this purpose.

Tree breeders aim to maximise the profitability of forestbased enterprises by deploying genetically improved planting stock from breeding programs, based on the selection, crossing, and testing of a range of genotypes. However, before breeding commences, tree breeders should (i) define a breeding objective; (ii) identify economically important biological traits that contribute to the objective (i.e. define "objective traits"); (iii) weight objective traits according to their economic importance to the objective; (iv) determine if there is exploitable genetic variation in objective traits; and (v) identify suitable surrogate traits (i.e. "selection traits", sometimes referred to as "selection criteria") that can be used to indirectly select for objective traits, and thus for the objective. Ideally, selection traits should be strongly genetically correlated with objective traits, and feasible and cost effective to assess at a relatively young age (Ponzoni and Newman, 1989). However, at the commencement of a breeding program it is very rare that all relevant information is available to breeders. Accordingly, breeders are generally required to estimate economic and genetic parameters based on their understanding of underlying economic and biological processes, and/or empirical data from other species.

In the case of E. globulus, extensive production system modelling of the pulpwood production process has been undertaken (Greaves et al., 1997). These studies identified stand volume per unit area, basic density and pulp yield at rotation age as the most economically important pulpwood objective traits and determined economic weights for each of these traits based on cost savings per tonne of pulp produced. Early-age diameter at breast height over bark (DBH, $1.3 \mathrm{~m}$ ), and Pilodyn penetration (or core basic density) (Downes et al., 1997) are commonly used as selection traits in Eucalyptus globulus pulpwood breeding programs, based on the premise that they are strongly genetically correlated with the objective traits of rotation-age stand volume and whole-tree basic density respectively.

Breeding for appearance-grade sawn timber from E. globulus is less advanced than breeding for pulpwood production. The development of a breeding objective for appearance-grade sawn-timber is an ongoing process, made difficult because markets for plantation-grown E. globulus timber are not mature and there is continual innovation in the sawmilling sector. However, appearance-grade sawn-timber objective traits are likely to include rotation-age stand volume, log diameter, and traits affecting green and dried recovery, the quality of appearance-grade products and by-product value (e.g. pulpwood traits) (Greaves et al., 2004; Nolan et al., 2005; Raymond, 2000). Specific traits that affect dried recovery and the quality of appearance-grade products include drying defects, such as internal checking (i.e. radially-oriented cracks that do not extend to the surface of a board) (Nolan et al., 2005; Nutto and Vazquez, 2004; Washusen et al., 2000; Waugh, 2004) and, for some applications such as flooring, resistance to indentation (i.e. hardness) (Bootle, 2002; Nolan et al., 2005). Possible selection traits for appearance-grade sawn-timber breeding include early-age assessment of DBH, Pilodyn penetration, core basic density and core shrinkage properties.

The principal aims of this study were to: (i) test if the potential pulpwood and sawn-timber objective traits of rotation-age whole-tree volume and survival (the components of stand volume), whole-tree basic density, sawn-board Janka hardness, and sawn-board internal checking are under significant genetic control; and (ii) test the significance from zero, and estimate the strength and direction, of subrace and within-subrace additive genetic correlations between these objective traits, and the possible selection traits of DBH, Pilodyn penetration, woodsample basic density and wood-sample gross shrinkage.

\section{MATERIALS AND METHODS}

\subsection{Trial}

This study was undertaken on trees planted in a Gunns Ltd. E. globulus base population progeny trial growing at West Ridgley $\left(41^{\circ} 08^{\prime} \mathrm{S}, 145^{\circ} 48^{\prime} \mathrm{E}\right)$ in north-western Tasmania. West Ridgley receives an average annual rainfall of approximately $1250 \mathrm{~mm}$ with an annual mean temperature of $10.8{ }^{\circ} \mathrm{C}$ and is at an elevation of $180 \mathrm{~m}$. This study used data from 116 of the 451 open-pollinated families and ten of the 21 subraces (Dutkowski and Potts, 1999) planted in the trial. The Strzelecki Ranges and Madalya Road subraces were treated as one in this study.

The trial was a resolvable incomplete block design divided into two areas, herein referred to as blocks, approximately $150 \mathrm{~m}$ apart. These blocks contained two and three replicates respectively, each with 23 incomplete blocks. Families were planted in two-tree rowplots. Seedlings were established at a spacing of 2 by $4.5 \mathrm{~m}$ and the trial was managed as a pulpwood stand without thinning or pruning.

\subsection{Assessment of objective traits}

\subsubsection{Volume}

Rotation-age stand volume per unit area is a function of average whole-tree volume, survival and planting density. However, the 
relationship between whole-tree volume and survival is likely to be different in two-tree plot progeny trials than in operational plantations for various reasons (e.g. in small-plot trials, competition between genotypes with different early-age growth/survival strategies could amplify rotation-age growth differences among these genotypes). Consequently, in this study it was not possible to obtain a meaningful estimate of a genotype's operational rotation-age stand volume per unit area and instead trial whole-tree volume and survival were examined separately.

Two hundred and fifty trees were felled at age fifteen years for the purposes of this and other studies. These were the same trees detailed in Hamilton et al. (2007) with one additional tree from each of the King Island and Southern Furneaux subraces. Wood discs, approximately $25 \mathrm{~mm}$ thick, were extracted from six heights within each felled tree. The mean height of discs within each of the height categories was $0 \%, 5 \%, 12 \%, 18 \%, 40 \%$ and $60 \%$ of tree height. Discs were placed in plastic bags immediately after extraction to minimise moisture loss.

Disc diameter under bark was measured on all felled trees using a diameter tape. Whole-tree volume under bark was calculated from individual disc measurements by treating each section of the stem as a frustum of a cone, with the top section treated as a cone (Raymond and MacDonald, 1998). Survival at rotation-age was assessed as a binary trait on all planted trees immediately prior to felling (excluding data from 57 trees felled in previous studies).

\subsubsection{Whole-tree basic density}

After diameter assessment, whole discs were deemed impractically large for processing and transport and were sawn through the pith into symmetrical half-discs. One half-disc was randomly selected to assess basic density and the other was discarded. Basic densities of the selected half-discs were measured using the water displacement method (Downes et al., 1997). Whole-tree density was calculated by weighting disc basic densities by the volume of the section of the stem that each disc represented. A disproportionately high number of the discs from near the base of trees broke during drying, probably due to their relatively large size, and were not assessed for basic density because labels were not attached to all disc fragments. For trees in which there was no estimate of basic density in the $0 \%$ or $60 \%$ height category (91 trees) no whole-tree estimate of this trait was calculated.

\subsubsection{Board traits}

A single $1.5 \mathrm{~m}$ sawlog was extracted from the straightest part of the lower stem in each tree (Hamilton et al., 2007). The sawlog was sawn where it fell using a portable chainsaw-mill to recover two 25mm-thick boards: one backsawn board and one bark-to-bark quartersawn board (i.e. a slab sawn as close as possible to the stem pith). Both boards were extracted so that they would have been oriented north-south in standing trees. Boards were wrapped in plastic immediately after extraction.

Boards were pre-dried in a kiln to a moisture-content of approximately $20 \%$. The harshness of pre-drying conditions within the kiln was progressively increased over a 74-day period (excluding days 50 through to 59, during which the kiln was shut down for repairs). Recorded kiln temperatures ranged from $18^{\circ} \mathrm{C}$ (dry bulb) and $17^{\circ} \mathrm{C}$ (wet bulb) initially to $25^{\circ} \mathrm{C}$ (dry bulb) and $21{ }^{\circ} \mathrm{C}$ (wet bulb) at day
60. The air speed was maintained at $0.5 \mathrm{~m} \mathrm{~s}^{-1}$ throughout pre-drying. The boards were then reconditioned (i.e. steamed) to recover collapse following a normal industrial procedure: boards were heated for two hours from ambient temperature to $98{ }^{\circ} \mathrm{C}$, retained at $98{ }^{\circ} \mathrm{C}$ for four hours and cooled for $14 \mathrm{~h}$. After reconditioning, final drying was undertaken in a kiln over $49 \mathrm{~d}$. Recorded kiln conditions ranged from $19.0{ }^{\circ} \mathrm{C}$ (dry bulb), $17{ }^{\circ} \mathrm{C}$ (wet bulb) and an air speed of $1.3 \mathrm{~m} \mathrm{~s}^{-1}$ initially to $65{ }^{\circ} \mathrm{C}$ (dry bulb), $50{ }^{\circ} \mathrm{C}$ (wet bulb) and an air speed of $2.0 \mathrm{~m} \mathrm{~s}^{-1}$ from day eight onwards.

After final drying, boards were assessed for the presence or absence of internal checks at board ends, although this trait was only assessed on the random sample (170) of the quartersawn boards. Janka hardness (Mack, 1979) was assessed, as a measure of resistance to indentation, at one point on clear wood halfway between the pith and bark on each quartersawn board.

\subsection{Selection traits}

As part of a previous study (MacDonald et al., 1997), DBH over bark was measured on all surviving trees ( $91 \%$ of the planted trees) in the trial at age four years (DBH4) and Pilodyn penetration was measured at age $5 \frac{1}{2} 2$ y on one tree per plot in two of the five replicates. Trees in the top $10 \%$ for DBH were also measured for Pilodyn penetration.

Because not all selection traits of interest were assessed at selection age, it was necessary to assess sample basic density and gross shrinkage at the time of felling. For this purpose, $12 \times 12 \mathrm{~mm}$ samples were cut from directly below the sawlog (12\% of tree height, $\sim 3.0 \mathrm{~m})$ in each felled tree (for details, refer to Hamilton et al., 2009) to imitate cylindrical cores. Such cores are routinely extracted from standing trees for selection purposes (Downes et al., 1997). Decay was observed near the pith in samples from $51 \%$ of trees and was removed prior to basic density and gross shrinkage measurement. Sample basic density was assessed according to the water displacement method on samples dried at $105{ }^{\circ} \mathrm{C}$ (Downes et al., 1997). After drying, the point of minimum tangential width on each side of the pith was also measured on each sample using callipers. Gross shrinkage was calculated as the difference between green sample width (i.e. $12 \mathrm{~mm}$ ) and the mean minimum tangential width divided by the green sample width (Hamilton et al., 2009). DBH was also assessed on all surviving trees (46\% of the planted trees) in the trial immediately prior to felling (DBH15).

\subsection{Statistical Analyses}

For each selection and objective trait, all available data from trees in the ten studied subraces were utilised in analyses. Univariate restricted maximum likelihood (REML) mixed model analyses were undertaken for each trait. Although not all variables were included in the analysis of each trait (Tab. I), the full linear model was:

$$
\begin{aligned}
Y= & \text { MEAN }+ \text { BLOCK }+ \text { HEIGHT }+ \text { DECAY + SUBRACE } \\
& +R E P(\text { BLOCK })+I B L K(\mathrm{REP})+\text { PLOT }(\mathrm{IBLK}) \\
& +F A M(\mathrm{SUBRACE})+\text { RES IDUAL }
\end{aligned}
$$

where $Y$ is a vector of observations, MEAN is the trait mean, BLOCK are block effects fitted as a fixed factor, HEIGHT are percentage heights of sample extraction fitted as a covariate, DECAY are decay effects (two levels: decay removed and decay not removed from 
Table I. Terms included in the model used to analyse each trait.

\begin{tabular}{|c|c|c|c|c|c|c|c|c|c|}
\hline \multicolumn{2}{|l|}{ Trait } & BLOCK & HEIGHT & DECAY & SUBRACE & $\begin{array}{c}R E P(\mathrm{BLOCK}) \\
*\end{array}$ & $I B L K(\mathrm{REP})$ & $P L O T$ (IBLK) & $F A M(\mathrm{SUBRACE})$ \\
\hline Whole-tree basic d & nsity & $\checkmark$ & & & $\checkmark$ & $*$ & & & $\checkmark$ \\
\hline \multirow[t]{2}{*}{ Internal checking** } & - Quartersawn & $\checkmark$ & $\checkmark$ & & $\checkmark$ & $*$ & & & $\checkmark$ \\
\hline & - Backsawn & $\checkmark$ & $\checkmark$ & & $\checkmark$ & $*$ & & & $\checkmark$ \\
\hline DBH15 & & $\checkmark$ & & & $\checkmark$ & $\checkmark$ & $\checkmark$ & * & $\checkmark$ \\
\hline DBH4 & & $\checkmark$ & & & $\checkmark$ & $\checkmark$ & $\checkmark$ & * & $\checkmark$ \\
\hline Pilodyn Penetration & & $\checkmark$ & & & $\checkmark$ & $\checkmark$ & $\checkmark$ & $*$ & $\checkmark$ \\
\hline
\end{tabular}

* Term was not included in final model as it was found to be non-significant.

${ }^{* *}$ A binomial model was fitted with a probit link function.

the $12 \times 12 \mathrm{~mm}$ sample) fitted as a fixed factor, SUBRACE are subrace effects fitted as a fixed factor, $R E P(\mathrm{BLOCK})$ are replicate within block effects fitted as a random factor, $I B L K(\mathrm{REP})$ are incomplete block within replicate effects fitted as a random factor, PLOT(IBLK) are plot within incomplete block effects fitted as a random factor, FAM(SUBRACE) are family within subrace effects fitted as a random factor and RESIDUAL is a vector of residuals. Univariate analyses of survival and internal checking, assessed as binary traits, used binomial models with a probit link function.

Analysis of DECAY as a dependent variable did not reveal a significant subrace or family within subrace effect. This indicated that DECAY could be fitted as a covariate in analyses without introducing significant bias according to a genotype's propensity to exhibit decay.

Overall and subrace least-squares means were estimated for each trait. For analyses in which HEIGHT and DECAY were fitted, these means were estimated at $12 \%$ of tree height assuming no decay was removed from samples. The significance of the SUBRACE term in each analysis was gauged with an F-test using the FAM(SUBRACE) term as the error.

For each trait, the additive variance $\left(\sigma_{\mathrm{a}}^{2}\right)$, phenotypic variance $\left(\sigma_{\mathrm{p}}^{2}\right)$, narrow-sense open-pollinated heritability $\left(h_{\mathrm{op}}^{2}\right)$ and coefficient of additive genetic variance $\left(C V_{\mathrm{a}}\right)$ were estimated from univariate analyses as follows:

$$
\begin{gathered}
\sigma_{\mathrm{a}}^{2}=\frac{\sigma_{\mathrm{f}}^{2}}{r} \\
\sigma_{\mathrm{p}}^{2}=\sigma_{\mathrm{f}}^{2}+\sigma_{\mathrm{e}}^{2} \\
h_{\mathrm{op}}^{2}=\frac{\sigma_{\mathrm{a}}^{2}}{\sigma_{\mathrm{p}}^{2}} \\
C V_{\mathrm{a}}=100 \times \frac{\sqrt{\sigma_{\mathrm{a}}^{2}}}{\bar{x}}
\end{gathered}
$$

where $\sigma_{\mathrm{f}}^{2}$ is the family within subrace variance; $\sigma_{\mathrm{e}}^{2}$ is the residual variance; $r$ is the coefficient of relationship, fixed to equal 0.4 to account for an assumed selfing rate of $30 \%$; and $\bar{x}$ is the trait least-squares mean. The significance of the family within subrace variance and, by implication, additive variance for each trait was tested with a onetailed likelihood ratio test (Gilmour et al., 2006).

A bivariate model, which extended the univariate model and allowed for covariation between random effects (Gilmour et al., 2006) was used to estimate pairwise within-subrace additive genetic correlations (herein referred to as "genetic correlations") between traits and drying treatments using the following function:

$$
r_{\mathrm{g}}=\frac{\sigma_{\mathrm{f}_{12}}}{\sqrt{\sigma_{\mathrm{f}_{1}}^{2} \sigma_{\mathrm{f}_{2}}^{2}}}
$$

where $\sigma_{\mathrm{f}_{12}}$ is the family within subrace covariance component between traits (or drying treatments) 1 and 2 and $\sigma_{\mathrm{f}_{1}}^{2}$ and $\sigma_{\mathrm{f}_{2}}^{2}$ are the family within subrace variances for traits (or drying treatments) 1 and 2 . Difficulties with convergence precluded the use of a full multivariate model for the purpose of calculating genetic correlations. Two-tailed likelihood ratio tests were conducted to determine if genetic correlations were significantly different from zero and one-tailed likelihood ratio tests were used to determine if genetic correlations were significantly different from one or minus one, as appropriate (Gilmour et al., 2006).

Pearson correlation-coefficients among inter-trait subrace least square means, herein referred to as "subrace correlations", and among individual-tree phenotypic values, herein referred to as "phenotypic correlations" were estimated. Two-tailed t-tests were used to test if subrace and phenotypic correlations were significantly different from zero. Analyses were conducted using ASReml ${ }^{\mathrm{TM}}$ (Gilmour et al., 2006) and $\mathrm{SAS}^{\mathrm{TM}}$ (version 9.1).

\section{RESULTS}

A significant $(P<0.05)$ subrace effect was observed in all traits, although only in quartersawn boards in the case of internal checking (Tab. II). King Island had the greatest DBH and whole-tree volume, and also exhibited a high level of survival, at age $15 \mathrm{y}$. Indeed, in combination, differences in harvest-age whole-tree volume and survival resulted in a three-fold difference between the best (King Island, $510 \mathrm{~m}^{3} \mathrm{ha}^{-1}$ ) and worst (South-eastern Tasmania, $170 \mathrm{~m}^{3} \mathrm{ha}^{-1}$ ) subraces in terms of volume per unit area within the trial. The Strzelecki Ranges subrace had the highest sample and whole-tree basic densities, and the lowest Pilodyn penetration. Whole-tree basic densities were substantially higher than sample basic densities in all subraces. Cape Patton and King Island had the lowest Janka hardness and Strzelecki Ranges the highest. Western Tasmania and King Island were observed to have substantially higher levels of internal checking than other subraces in quartersawn 


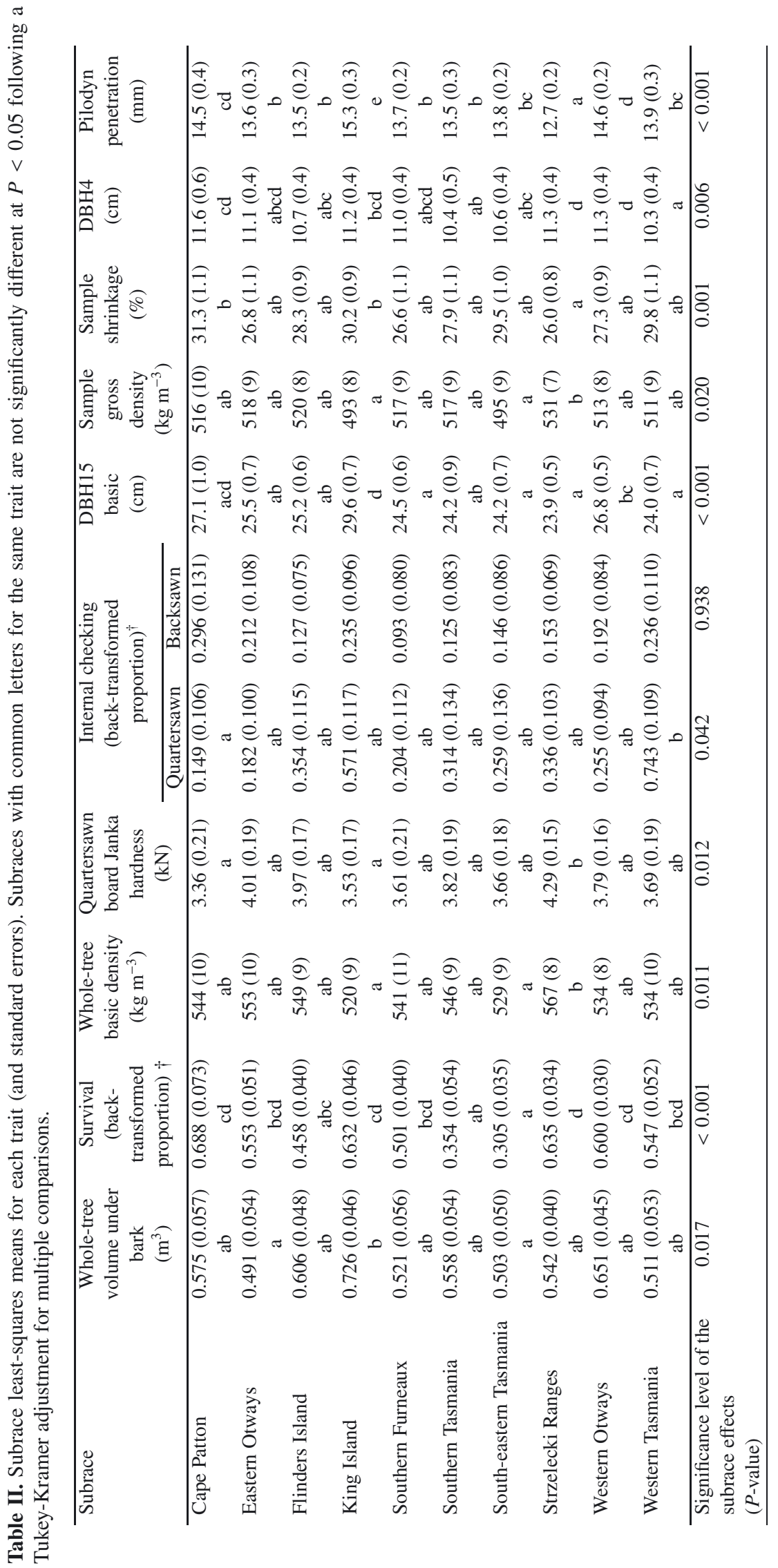


boards. In most subraces, a greater proportion of quartersawn boards than backsawn boards contained internal checking.

Significant additive genetic variation within races was detected in all traits, although for internal checking this was true only for backsawn boards ( $P=0.286$ for quartersawn boards) (Tab. III). The heritability for whole-tree volume was substantially greater than that for DBH at the same age. Similarly, the heritability for whole-tree basic density was greater than that for both Pilodyn penetration and sample basic density. Heritabilities for the objective traits of survival, hardness and backsawn internal checking were also high to very high.

As is commonly observed in eucalypts (Hamilton and Potts, 2008; Potts et al., 2004), the coefficient of additive genetic variation was greater in the growth traits of DBH4, DBH15 and whole-tree volume than the wood property traits of Pilodyn penetration and basic density (Tab. III). However, the coefficient of additive genetic variation for Janka hardness was higher than that observed for other wood-quality traits.

The genetic correlation between DBH4 and DBH15 was significantly different from both zero (Tab. IV) and one $(P<$ $0.001)$. However, that between Pilodyn penetration at age $5^{1 / 2}$ y and sample basic density at age 15 y was significantly different from zero but not significantly different from minus one $(P=0.077)$. The subrace correlations between these traits were weaker than corresponding genetic correlations and that between DBH4 and DBH15 was not significantly different from zero $(P=0.066)$.

The genetic correlations for early-age DBH with rotationage whole-tree volume and survival were strong and although significantly different from zero (Tab. V) were also significantly different from one $(P=0.046$ and $P<0.001$ respectively). However, the subrace correlation between DBH4 and volume was weak and not significantly different from zero $(P=0.259)$. The subrace correlation between DBH15 and volume was high $\left(r_{\mathrm{s}}=0.84, \mathrm{SE}=0.19\right)$ and significantly different from zero $(P=0.003)$, but that between DBH15 and survival was weaker $\left(r_{\mathrm{s}}=0.48, \mathrm{SE}=0.13\right)$.

Both subrace and genetic correlations between Pilodyn penetration at age $5^{1 / 2}$ y and whole-tree basic density at age $15 \mathrm{y}$ were strong and significantly different from zero and the genetic correlation was not significantly different from minus one $(P=0.298)$. However, the genetic correlation between Pilodyn penetration and Janka hardness was more moderate and, while significantly different from zero (Tab. V), was also different from minus one $(P=0.035)$.

All calculated subrace and genetic correlations between sample gross shrinkage and internal checking in boards were positive but none were significantly different from zero (Tab. V). However, while low at 0.22 , the phenotypic correlation for backsawn boards was significantly different from zero $(P<0.001)$. The subrace and genetic correlations of sample gross shrinkage with Janka hardness were strongly negative and significantly different from zero.

\section{DISCUSSION}

\subsection{Volume and survival}

The weak and non-significant subrace correlation between DBH4 and volume was no doubt partly a reflection of the weak correlation between DBH4 and DBH15, as the correlation between DBH15 and volume was strong. This weak correlation was indicative of age-by-subrace interaction. Such interaction, could have been the result of numerous factors, including differential size-dependent mortality impacting on the mean size of survivors (Chambers et al., 1996) and/or reduced withinplot competition resulting in more rapid growth of survivors. Alternatively, this age-by-subrace interaction could have been due to differences in growth strategies, such as variation in the timing of phase change (Jordan et al., 2000), flowering precocity (Chambers et al., 1997) and/or above to below ground biomass allocation; response to competition; or adaptation to biotic or abiotic stresses that impacted on the trial over the growth interval (e.g. frosts; Tibbits et al., 2006; drought; Costa e Silva et al., 2006; or pests; Jordan et al., 2002; Rapley et al., 2004).

The strong genetic correlations within subraces for DBH4 with both rotation-age survival and whole-tree volume, and, by implication, stand volume per unit area, support the inclusion of early-age DBH as a selection trait in E. globulus breeding programs. However, the poor correlation between DBH4 and whole-tree volume at the subrace level suggest that early-age indirect selection for rotation-age volume might be less efficient than the within-subrace genetic correlation suggests, although the correlation is still high with rotation-age survival. The efficiency of selection for stand-level volume based on early-age DBH measurements warrants further investigation.

\subsection{Basic density}

The mean of whole-tree basic density was comparable to previous estimates for $E$. globulus felled at a similar age (McKinley et al., 2002; Quilho and Pereira, 2001; Raymond and MacDonald, 1998). Furthermore, the mean sample basic density at $12 \%$ of tree height was lower than whole-tree basic density, consistent with the repeatedly-observed longitudinal trend towards greater basic density with height (Hamilton et al., 2007; McKinley et al., 2002; Quilho and Pereira, 2001; Raymond and MacDonald, 1998). The relative performance of subraces in terms of whole-tree basic density were broadly consistent with those for both sample basic density and Pilodyn penetration in this study and others (Dutkowski and Potts, 1999; Lopez et al., 2001; Muneri and Raymond, 2000).

The very high heritability of whole-tree basic density probably reflected the high precision of whole-tree phenotypic measurements and the strong additive genetic control of basic density. The strong additive genetic control of basic density in E. globulus was also reflected in the high, albeit lower, heritabilities of sample basic density and Pilodyn penetration assessed in this and other studies (Costa e Silva et al., 2009; Potts et al., 2004; Volker et al., 2008). However, despite its 


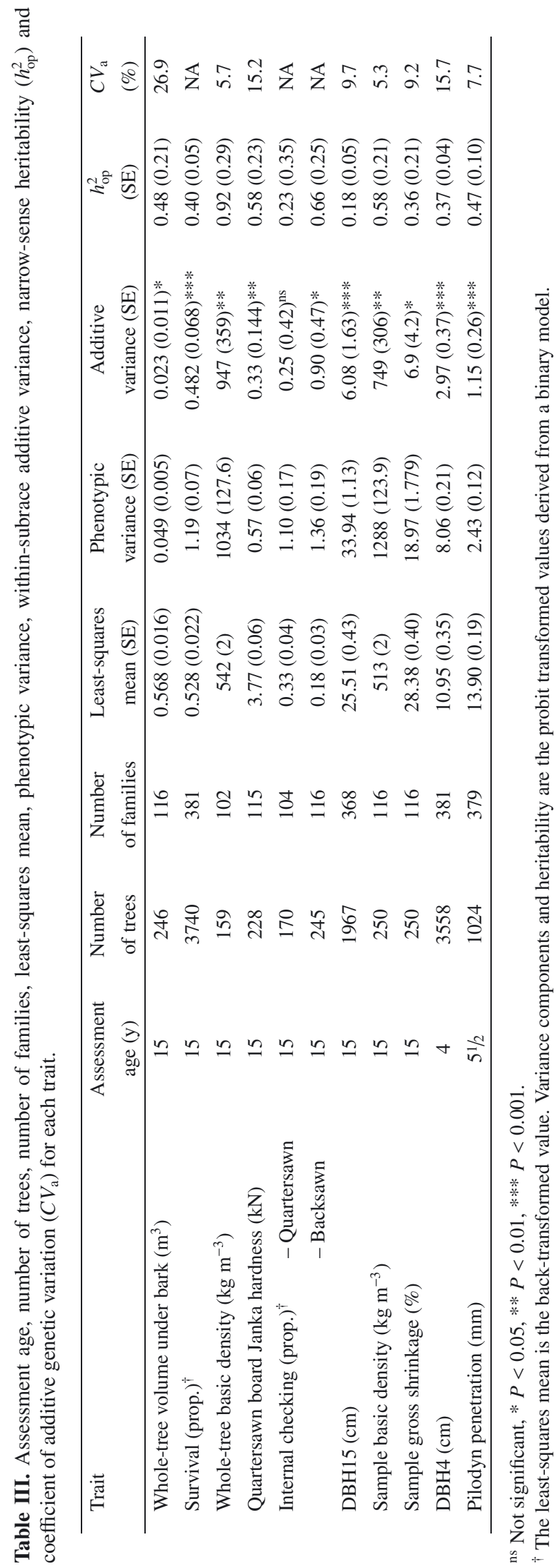


Table IV. Intertrait subrace, genetic and phenotypic correlations (and standard errors) among selection-age and rotation-age selection traits.

\begin{tabular}{llcc}
\hline Rotation-age trait & Selection-age trait & Type & Correlation \\
\hline DBH15 & DBH4 & Subrace & $0.60(0.28)^{\mathrm{ns}}$ \\
& & Genetic & $0.88(0.04)^{* * *}$ \\
& & Phenotypic & $0.63(0.02)^{* * *}$ \\
\hline Sample basic density & Pilodyn penetration & Subrace & $-0.70(0.25)^{*}$ \\
& & Genetic & $-0.75(0.18)^{* * *}$ \\
& & Phenotypic & $-0.50(0.07)^{* * *}$ \\
\hline
\end{tabular}

${ }^{\mathrm{ns}}$ Not significantly different from zero, $* P<0.05, * * P<0.01$, *** $P<0.001$

Table V. Intertrait subrace, genetic and phenotypic correlations (and standard errors) between selection traits and objective traits.

\begin{tabular}{|c|c|c|c|c|}
\hline \multirow[b]{2}{*}{$\begin{array}{l}\text { Objective trait } \\
(15 \mathrm{y})\end{array}$} & \multirow[b]{2}{*}{ Correlation } & \multicolumn{3}{|c|}{ Selection trait } \\
\hline & & $\begin{array}{l}\text { DBH4 } \\
(4 \mathrm{y})\end{array}$ & $\begin{array}{l}\text { Pilodyn penetration } \\
\text { penetration } \\
\left(5^{1} / 2 \mathrm{y}\right)\end{array}$ & $\begin{array}{c}\text { Sample gross } \\
\text { shrinkage } \\
(15 \mathrm{y})\end{array}$ \\
\hline \multirow[t]{3}{*}{ Whole-tree volume under bark } & Subrace & $0.39(0.32)^{\mathrm{ns}}$ & $0.72(0.25)^{*}$ & $0.28(0.34)^{\mathrm{ns}}$ \\
\hline & Genetic & $0.78(0.12)^{* * *}$ & $0.31(0.26)^{\mathrm{ns}}$ & $-0.24(0.39)^{\mathrm{ns}}$ \\
\hline & Phenotypic & $0.53(0.05)^{* * *}$ & $0.23(0.08) * *$ & $0.08(0.06)^{\mathrm{ns}}$ \\
\hline \multirow[t]{3}{*}{ Survival } & Subrace & $0.78(0.22)^{* *}$ & $0.36(0.33)^{\mathrm{ns}}$ & $0.10(0.35)^{\mathrm{ns}}$ \\
\hline & Genetic & $0.82(0.04) * * *$ & $0.29(0.12)^{*}$ & $-0.35(0.31)^{\mathrm{ns}}$ \\
\hline & Phenotypic & $0.50(0.01)^{* * *}$ & $0.06(0.03)^{\mathrm{ns}}$ & - \\
\hline \multirow[t]{3}{*}{ Whole-tree basic density } & Subrace & $0.13(0.35)^{\mathrm{ns}}$ & $-0.83(0.20)^{* *}$ & $-0.61(0.28)^{\mathrm{ns}}$ \\
\hline & Genetic & $-0.06(0.21)^{\mathrm{ns}}$ & $-0.91(0.15)^{* * *}$ & $-0.78(0.30)^{*}$ \\
\hline & Phenotypic & $0.03(0.08)^{\mathrm{ns}}$ & $-0.61(0.08) * * *$ & $-0.46(0.07)^{* * *}$ \\
\hline \multirow[t]{3}{*}{ Janka hardness } & Subrace & $-0.11(0.35)^{\mathrm{ns}}$ & $-0.75(0.23)^{*}$ & $-0.77(0.22)^{* *}$ \\
\hline & Genetic & $0.26(0.22)^{\mathrm{ns}}$ & $-0.58(0.23)^{*}$ & $-0.73(0.33)^{*}$ \\
\hline & Phenotypic & $0.00(0.07)^{\mathrm{ns}}$ & $-0.43(0.08)^{* * *}$ & $-0.37(0.06)^{* * *}$ \\
\hline Internal checking & Subrace & $-0.46(0.31)^{\mathrm{ns}}$ & $0.23(0.34)^{\mathrm{ns}}$ & $0.33(0.33)^{\mathrm{ns}}$ \\
\hline \multirow[t]{2}{*}{ - Quartersawn } & Genetic & NA & NA & NA \\
\hline & Phenotypic & $-0.08(0.08)^{\mathrm{ns}}$ & $0.09(0.09)^{\mathrm{ns}}$ & $0.10(0.08)^{\mathrm{ns}}$ \\
\hline Internal checking & Subrace & NA & NA & NA \\
\hline \multirow[t]{2}{*}{ - Backsawn } & Genetic & $-0.02(0.21)^{\mathrm{ns}}$ & $0.15(0.24)^{\mathrm{ns}}$ & $0.51(0.30)^{\mathrm{ns}}$ \\
\hline & Phenotypic & $-0.01(0.06)^{\mathrm{ns}}$ & $0.01(0.08)^{\mathrm{ns}}$ & $0.22(0.06)^{* * *}$ \\
\hline
\end{tabular}

NA Correlations were not calculated if one or more of the traits being compared did not reveal significant differences among genotypes at the $P=0.200$ level. ${ }^{\mathrm{ns}}$ Not significantly different from zero, $* P<0.05$, ** $P<0.01$, *** $P<0.001$.

high heritability, response to selection in any one generation of breeding for increased whole-tree basic density is unlikely to be large relative to the overall trait mean, due to its comparatively narrow range of subrace means, from $520 \mathrm{~kg} \mathrm{~m}^{-3}$ for King Island to $567 \mathrm{~kg} \mathrm{~m}^{-3}$ for Strzelecki Ranges, and relatively low coefficient of additive genetic variation within subraces (Houle, 1992). Nevertheless, small gains in this trait may be of substantial economic importance to plantation growers (Greaves et al., 1997).

The strong subrace and genetic correlations between Pilodyn penetration and whole-tree basic density suggest that genetic gains in whole-tree basic density could be achieved at both the subrace and within-subrace level by selecting accord- ing to early-age Pilodyn penetration, a trait that can be assessed non-destructively and relatively cheaply. Furthermore, strong subrace and genetic correlations between sample basic density and Pilodyn penetration were observed; despite the considerable differences between assessment methods, tree ages and heights of assessment; suggesting that there is limited genotype-by-selection-method, genotype-by-age or genotypeby-height interaction in basic density.

\subsection{Janka hardness}

The Janka hardness of the boards in this study $(\bar{x}=3.8 \mathrm{kN})$ was low compared with commercially available eucalypt 
flooring products (Australian Hardwood Network, 2003), suggesting that, without improvement, 15-year-old plantationgrown E. globulus sawn timber may have difficulty gaining market acceptance as a flooring product in Australia. Furthermore, although comparable with the findings of Heng (1988; 3.11 to $6.83 \mathrm{kN}$ for 33-year-old plantation-grown E. globulus), the mean Janka hardness was considerably lower than that reported by Bootle (2002) (12 kN) for dried E. globulus most likely sourced from older native forest. Hardness has been observed to increase from pith to bark in eucalypts (Heng, 1988) and would, consequently, be expected to increase with age.

Janka hardness was not only under strong genetic control, as indicated by the significant subrace variation and high heritability of this trait, but the wide range of subrace means and high coefficient of additive genetic variation also indicated that there was a relatively large amount of exploitable genetic variation in this trait. These findings have positive implications for tree breeders aiming to improve sawn-timber hardness.

It is commonly accepted that hardness is positively correlated with basic density at the phenotypic level (Nolan et al., 2005; Silva et al., 1992). Furthermore, it might be expected that collapse-prone cells (i.e. cells unable to withstand tension forces generated as free water is removed from them) would be less able to withstand compressive forces and, thus, exhibit lower hardness. Although phenotypic correlations of Janka hardness with Pilodyn penetration and sample gross shrinkage were only weak to moderate, they were highly significantly different from zero, and reflected these theoretical relationships. Furthermore, the corresponding subrace and genetic correlations, which were moderately to strongly negative, indicated that these traits could be used to indirectly select for higher Janka hardness in breeding programs. These correlations also implied that any improvement (i.e. increases) in whole-tree basic density achieved through pulpwood breeding would result in a correlated increase in sawn-timber hardness.

\subsection{Internal checking}

Internal checking was observed in a high proportion of quartersawn $(\bar{x}=0.33)$ and backsawn $(\bar{x}=0.18)$ boards. Internal checking was found to be under significant genetic control at the subrace level in quartersawn boards and additive withinsubrace level in backsawn boards. However, there was no clear explanation as to why genetic variation was expressed at different levels in boards sawn using different sawing strategies. It is possible that the drivers of internal checking are different in quartersawn and backsawn boards and that these should be viewed as different traits in breeding programs. However, if a continuous rather than binary measure of checking had been used; genetic variation in this trait may have been more readily detected. Future studies of genetic variation in internal checking should also be undertaken on trials managed for solid-wood production to remove the confounding effect of pulpwood silviculture on this solid-wood trait.

Although subrace and genetic correlations between sample gross shrinkage and internal checking were positive, they were weak to moderate and not significantly different from zero, indicating that sample gross shrinkage may not be a useful indirect selection tool for breeding purposes. However, it is noteworthy that, despite the relatively small sample size and imprecise phenotyping of internal checking, a positive and highly significant phenotypic correlation between sample gross shrinkage and backsawn internal checking was detected.

In conclusion, this study suggests that genetic improvement of rotation-age whole-tree volume, survival, whole-tree basic density, sawn-board hardness and internal checking is possible through selective breeding. At the subrace level, DBH assessed at an early age proved to be a poor predictor of wholetree volume at rotation age. However, within subraces, strong and significant genetic correlations indicated that DBH, pilodyn penetration and/or sample basic density could be used as effective indirect selection tools for rotation-age stand volume, whole-tree basic density and board hardness. Neither subrace nor genetic correlations between sample gross shrinkage and internal checking in boards were significantly different from zero, possibly due to the relatively small sample size and binary, rather than quantitative, assessment of internal checking. Furthermore, the findings of this study are based on results from one trial site and additional studies are required to ensure that they are applicable to a wider range of environments and silvicultural regimes.

Acknowledgements: Funding for this project was provided by Australian Research Council linkage grants C00107465 (supported by the Southern Tree Breeding Association, STBA) and LP0453704 (supported by the Gunns Ltd., the Forests and Forest Industries Council of Tasmania, the STBA, Forestry Tasmania, RAIZ, seedEnergy Pty. Ltd., Timbercorp Ltd. and WA Plantation Resources Ltd.) and the CRC for Sustainable Production Forestry. We thank Gunns Ltd for access to the field trial and use of their facilities. We also thank René Vaillancourt, Luis Apiolaza, Stephen Aitken, Linda Ballard, Tony Blythe, Jonathon Cock, Chris Harwood, Trevor Innes, Leigh Johnson, Kelsey Joyce, Ravinish Kumar, Robert Lewis, Michael Oates, Andrew Prins, Chris Schoenmaker, Paul Tilyard, Renate Van Riet, Tim Watson and Stephen Wright for their assistance.

\section{REFERENCES}

Australian Hardwood Network, 2003. Australian hardwood and cypress manual. Australian Hardwood Network, NSW.

Bootle K.R., 2002. Wood in Australia: types, properties, uses. 2nd ed., McGraw-Hill, Sydney, p. 452.

Chambers P.G.S., Borralho N.M.G., and Potts B.M., 1996. Genetic analysis of survival in Eucalyptus globulus ssp. globulus, Silvae Genet. 45: 107-112.

Chambers P.G.S., Potts B.M., and Tilyard P.A., 1997. The genetic control of flowering precocity in Eucalyptus globulus ssp. globulus, Silvae Genet. 46: 207-214.

Costa e Silva J., Potts B.M., and Dutkowski G.W., 2006. Genotype by environment interaction for growth of Eucalyptus globulus in Australia, Tree Genet, Genomes 2: 61-75.

Costa e Silva J., Borralho N., Araújo J., Vaillancourt R., and Potts B., 2009. Genetic parameters for growth, wood density and pulp yield in Eucalyptus globulus, Tree Genet. Genomes 5: 291-305.

Downes G.M., Hudson I.L., Raymond C.A., Dean G.H., Michell A.J., Schimleck L.R., Evans R., and Muneri A., 1997. Sampling plantation 
eucalypts for wood and fibre properties. CSIRO Publishing, Melbourne, Victoria, p. 132.

Dutkowski G.W. and Potts B.M., 1999. Geographic patterns of genetic variation in Eucalyptus globulus ssp. globulus and a revised racial classification, Aust. J. Bot. 47: 237-263.

Gilmour A.R., Gogel B.J., Cullis B.R., and Thompson R., 2006. ASReml User Guide Release 2.0, VSN International Ltd, Hemel Hempstead, UK, p. 320.

Greaves B.L., Borralho N.M.G., and Raymond C.A., 1997. Breeding objective for plantation eucalypts grown for production of kraft pulp, For. Sci. 43: 465-472.

Greaves B.L., Dutkowski G., and McRae T., 2004. Breeding objectives for Eucalyptus globulus for products other than kraft pulp, In: Borralho N., Pereira J.S., Marques C., Coutinho J., Madeira M., and Tomé M. (Eds.), Eucalyptus in a changing world. Proceedings of an IUFRO conference, RAIZ, Aveiro, Portugal, pp. 175-180.

Hamilton M.G. and Potts B.M., 2008. Review of Eucalyptus nitens genetic parameters, N. Z. J. For. Sci. 38: 102-119.

Hamilton M.G., Greaves B.L., Potts B.M., and Dutkowski G.W., 2007. Patterns of longitudinal within-tree variation in pulpwood and solidwood traits differ among Eucalyptus globulus genotypes, Ann. For. Sci. 64: 831-837.

Hamilton M.G., Harwood C.E., and Potts B.M., 2009. The effects of drying temperature and method of assessment on the expression of genetic variation in gross shrinkage of Eucalyptus globulus wood samples, Silvae Genet. 58: 252-261.

Heng O.S., 1988. Notes on some properties of Eucalyptus globulus. Forest Research Centre, Sandakan, Malaysia, p. 7.

Houle D., 1992. Comparing evolvability and variability of quantitative traits, Genetics 130: 195-204.

Jordan G.J., Potts B.M., Chalmers P., and Wiltshire R.J.E., 2000. Quantitative genetic evidence that the timing of vegetative phase change in Eucalyptus globulus ssp. globulus is an adaptive trait, Aust. J. Bot. 48: 561-567.

Jordan G.J., Potts B.M., and Clarke A.R., 2002. Susceptibility of Eucalyptus globulus ssp. globulus to sawfly (Perga affinis ssp. insularis) attack and its potential impact on plantation productivity, For. Ecol. Manage. 160: 189-199.

Lopez G.A., Potts B.M., Dutkowski G.W., and Traverso J.M.R., 2001. Quantitative genetics of Eucalyptus globulus: Affinities of land race and native stand localities, Silvae Genet. 50: 244-252.

MacDonald A.C., Borralho N.M.G., and Potts B.M., 1997. Genetic variation for growth and wood density in Eucalyptus globulus spp. globulus in Tasmania (Australia), Silvae Genet. 46: 236-241.

Mack J.J., 1979. Australian methods for mechanically testing small clear specimens of timber. CSIRO, Division of building research, p. 19.

McKinley R.B., Shelbourne C.J.A., Low C.B., Penellum B., and Kimberley M.O., 2002. Wood properties of young Eucalyptus nitens, E. globulus, and E. maidenii in Northland, New Zealand, N. Z. J. For. Sci. 32: 334-356.

Muneri A. and Raymond C.A., 2000. Genetic parameters and genotypeby-environment interactions for basic density, pilodyn penetration and stem diameter in Eucalyptus globulus, For. Genet. 7: 317-328.
Nolan G., Washusen R., Jennings S., Greaves B., and Parsons M., 2005. Eucalypt plantations for solid wood products in Australia - A review. Forest and Wood Products Research and Development Corporation, Melbourne, Victoria, p. 130.

Nutto L. and Vazquez M.C.T., 2004. High quality eucalyptus sawlog production. In: Borralho N., Pereira J.S., Marques C., Coutinho J., Madeira M., Tomé M. (Eds.), Eucalyptus in a changing world. Proceedings of an IUFRO conference, RAIZ, Aveiro, Portugal, pp. 658-666.

Parsons M., Gavran M., and Davidson J., 2006. Australia's plantations 2006. Bureau of Rural Sciences, Commonwealth of Australia, Canberra, Australia, p. 56.

Ponzoni R.W. and Newman S., 1989. Developing breeding objectives for Australian beef-cattle production, Anim. Prod. 49: 35-47.

Potts B., Vaillancourt R.E., Jordan G., Dutkowski G.W., Costa e Silva J., McKinnon G.E., Steane D.A., Volker P., Lopez G.A., Apiolaza L., Li Y., Marques C., and Borralho N., 2004. Exploration of the Eucalyptus globulus gene pool. In: Borralho N., Pereira J.S., Marques C., Coutinho J., Madeira M., and Tomé M. (Eds.), Eucalyptus in a changing world. Proceedings of an IUFRO conference, RAIZ, Aveiro, Portugal, pp. 46-61.

Quilho T. and Pereira H., 2001. Within and between-tree variation of bark content and wood density of Eucalyptus globulus in commercial plantations, IAWA J. 22: 255-265.

Rapley L.P., Allen G.R., and Potts B.M., 2004. Genetic variation in Eucalyptus globulus in relation to susceptibility from attack by the southern eucalypt leaf beetle, Chrysophtharta agricola, Aust. J. Bot. 52: 747-756.

Raymond C.A., 2000. Tree breeding issues for solid wood production, The future of eucalypts for wood products. In: Proceedings of an IUFRO Conference, Forest Industries Association of Tasmania, Launceston, Tasmania, pp. 310-316.

Raymond C.A. and MacDonald A.C., 1998. Where to shoot your pilodyn: within tree variation in basic density in plantation Eucalyptus globulus and E. nitens in Tasmania, New For. 15: 205-221.

Silva D., Rocha J., and Moura J., 1992. Influência da densidade na dureza Janka em oito espécies madeireiras da Amazônia Central (Influence of density on Janka hardness in eight woody species from the central Amazon), Acta Amazonica 22: 275-283.

Tibbits W.N., White T.L., Hodge G.R., and Borralho N.M.G., 2006. Genetic variation in frost resistance of Eucalyptus glo-bulus ssp. globulus assessed by artificial freezing in winter, Aust. J. Bot. 54: 521-529.

Volker P.W., Potts B.M., and Borralho N.M.G., 2008. Genetic parameters of intra- and inter-specific hybrids of Eucalyptus globulus and $E$. nitens, Tree Genet. Genomes 4: 445-460.

Washusen R., Blakemore P., Northway R., Vinden P., and Waugh G., 2000. Recovery of dried appearance grade timber from Eucalyptus globulus Labill. grown in plantations in medium rainfall areas of the southern Murray-Darling Basin, Aust. For. 63: 277-283.

Waugh G., 2004. Growing Eucalyptus globulus for high-quality sawn products, In: Borralho N., Pereira J.S., Marques C., Coutinho J., Madeira M., and Tomé M. (Eds.), Eucalyptus in a changing world. Proceedings of an IUFRO conference, RAIZ, Aveiro, Portugal, pp. 79-84. 